Ethiopian Journal of Environmental Studies \& Management 7(3): 258 - 266, 2014.

ISSN:1998-0507

doi: http://dx.doi.org/10.4314/ejesm.v7i3.5

Submitted: December 16, 2013

Accepted: April 8, 2014

\title{
INFLUENCE OF ORGANIC WASTES AMENDMENT ON GROWTH AND FOLIAR YIELD OF JUTE MALLOW Corchorus olitorius (Linn.) IN SOUTH WESTERN NIGERIA
}

AWOTOYE, 0. O., MOKWENYE, A. I. AND *ADEBOLA, S. I.

Institute of Ecology and Environmental Studies Obafemi Awolowo University Ile-Ife, Nigeria

\begin{abstract}
This study investigated the growth and foliar yield responses of jute mallow (Corchorus olitorius Linn.) on soils amended with ashed and unashed corn cob and coconut husk agro-waste. Slightly acidic $(p H=6.20)$ sandy loam soil were collected and incubated for six and twelve weeks respectively for the study, with agro-wastes [coconut husk ash (CHA), coconut husk unashed (CHU), corn cob ash (CCA) and corn cob unashed (CCU)] under greenhouse conditions. A completely randomized design was adopted with three replicates. The results showed that the corn cob ash and coconut husk ash positively enhanced soil chemical properties than their unashed version. At $2 W A P$, the mean plant height ranged from $2.70 \pm 0.12 \mathrm{~cm}$ to $3.88 \pm 0.12 \mathrm{~cm}$; the mean total leaf count from $3.60 \pm 0.05$ to $4.0 \pm 0.05$ and mean leaf area from $0.54 \pm 0.21 \mathrm{~cm}^{2}$ to $2.48 \pm 0.21 \mathrm{~cm}^{2}$ and at 8 WAP, the mean stem girth ranged from $0.43 \pm 0.07 \mathrm{~cm}$ to $1.02 \pm 0.07 \mathrm{~cm}$ for C. olitorius planted in soils incubated for six weeks with agro-wastes. This trend increased with the age of $C$. olitorius and with increase in agro-waste applications in the order CCA $>C H A>C H U>C C U$. These growth parameters, except the plant height were of higher values in 6 weeks soil incubation than 12 weeks soil incubation. The highest mean yield (17.93 $\mathrm{g} / \mathrm{pot}$ ) of C. olitorius was obtained in soil pots amended for 12 weeks with $5 \mathrm{t} / \mathrm{ha}$ of $\mathrm{CHU}$. The increase growth and foliage yield obtained in this study showed that soils amended with ashed and unashed corn cob and coconut husk waste have the potential of promoting the production of vegetables, especially $C$. olitorius and also ensuring environmental sustainability.
\end{abstract}

Key Words: Agro-waste, Amended soil, Coconut hust, Corn cob, Corchorus olitorius, Greenhouse, Vegetable

\section{Introduction}

Vegetable production forms a substantial percentage (about $25 \%$ ) of the major food crops cultivated in the tropics and so it is the source of livelihood for a considerable section of the population (Kra and Bani, 1988). Corchorus olitorius popularly called "ayoyo" in Hausa and "ewedu" in Yoruba is a popular green vegetable plant (Musa et al., 2010). It is grown in both dry and semi-arid regions and in the humid areas of Africa, because of its importance in giving the body good nutrients (Oladiran, 1986). C. olitorius belongs to the Tiliaceae family and is an erect annual herb that varies from $60 \mathrm{~cm}$ to approximately $150 \mathrm{~cm}$ in height depending on the cultivar (Husselman and Sizane, 2006). The two most commonly found species of Jute mallow in Nigeria are C. capsularis and C. olitorius.

A sustainable production of vegetables to meet the demands of an ever increasing population in the country is of great concern (Oladoja et al., 2006). Vegetable production in
Nigeria is characterized by use of crude implements, non availability of inputs (Mofeke $e t$ al., 2003). Agboola and Unamma (1991) observed that one of the conditions to be satisfied in stabilizing agricultural systems in the humid tropics is to find means that will make soil organic matter adequately maintained at all times by preventing the amount already in the soil from being destroyed through cultural practices or by constantly adding organic materials to the soil. Application of organic matter on soil had shown to help crops to withstand drought, increased soil organic matter, nitrogen, $\mathrm{pH}$, phosphorus, and cation exchange capacity (CEC), and reduced soil exchangeable acidity (Adeniyan and Ojeniyi, 2003; Mbah, 2006; Ayeni et al., 2008; Alabadan et al., 2009; Adeleye et al., 2010; Njoku and Mbah, 2012). Several agricultural wastes such as; wood and sawdust ash on tomato and pepper yield (Odedina et al., 2003), bagasse ash on wheat yield (Jamil et al., 2004), cocoa pod ash on tomato yield (Ayeni, 2010), sawdust and poultry

*Corresponding Author: Adebola, S.I.

Email: adebolasamuel@gmail.com 


\section{Influence of Organic Wastes Amendment on Growth and Foliar Yield..................WOTOYE et al.}

manure on maize yield (Oladipo et al., 2010), burnt and unburnt rice husk on maize yield (Njoku and Mbah, 2012), have been used as soil amendment. All these agricultural wastes have been considered because of the menace that their accumulation tends to constitute on the environment and low yield that has been observed overtime in agricultural production in Nigeria. Corn cob and coconut husk have received little research attention from researchers in cultivation of vegetable especially $C$. olitorius. FMAWR (1988) stated that over 4.11 million tonnes of maize residue is generated in Nigeria. Coconut husks are residues generated during coconut processing which are available in abundant quantities in many parts of the tropics but are often treated as a waste material (Olorunnisola, 2009). This study focuses on the effect of ashed and unashed corn cob and coconut husk on growth performance and foliar yield of Corchorus olitorius in South-West Nigeria.

\section{Materials and Methods}

The study was carried out in the greenhouse of the Faculty of Agriculture, Obafemi Awolowo University, Ile-Ife. Viable seeds of Corchorus olitorius were purchased from Institute of Agricultural Research and Training (IAR\&T) Moor Plantation, Ibadan. The experiment consisted of a six and twelve weeks soil incubation of agro-wastes amendments (ashed and unashed corn cob and coconut husk) prior to planting. The agro-wastes (corn cob and coconut husk) samples were obtained within the university community and milled using a cassava grinding machine at the workshop of Agricultural Engineering Department of Obafemi Awolowo University, Ile-Ife. Half of the milled corn cob and coconut husk was ashed in the muffle furnace at $500^{\circ} \mathrm{C}$ for five minutes and the other half of the agro-waste samples were left unashed. The treatments were replicated three times in Completely Randomized Design (CRD). Top soil samples $(0-15 \mathrm{~cm})$ from exhaustively cropped farm land within the University was collected and mixed thoroughly. Seed viability test was conducted on seeds of $C$. olitorius. The germination rate was 84 percent which was used to determine the viability status of the test crop. The agro-waste amendments were applied at 0,5 and $10 \mathrm{t} / \mathrm{ha}$. A total of 72 plastic pots each of which had $3 \mathrm{~kg}$ of sieved air-dried soil were mixed with each treatment level. Thirty six pots were set aside for six weeks soil incubation and the other 36 pots for twelve weeks soil incubation. During the incubation of the amendments in the soil, the planting pots were covered with perforated plastic plates an approach adapted by Ayeni (2009). At the expiration of both incubation periods four seeds of $C$. olitorius was planted per pot and later thinned to two stands per pot at two weeks after planting. The pots were watered regularly and maintained weed free throughout the study.

\section{Plant Growth Measurement}

Plant height, total leaf count, leaf area and stem girth was monitored every two weeks interval. Plant height was measured with a metre rule from soil level to the terminal bud. The leaf area was determined using the formula Leaf Area $=\mathrm{L} \mathrm{x} \mathrm{W}$ $\mathrm{x} 2.325$, where $\mathrm{L}$ is the length, $\mathrm{W}$ is the width and 2.325 is the conversion factor. The stem girth was determined by putting a thread round the girth of the stem at about $1.5 \mathrm{~cm}$ above the soil and the thread was measured out on a metre rule. While the total leaf count was achieved by direct counting. At twelve weeks after planting, the plants were harvested and the roots were disassociated from the shoots. Fresh weight of shoot was determined using Kern and Sohn 44033 model electronic weighing balance. While dry weight of shoot was determined after being oven dried for 48 hours at $70^{\circ} \mathrm{C}$ using a Binder FED 400 model oven. A statistical comparison of means was made with analysis of variance (ANOVA) and treatment means were separated using LSD $(\mathrm{P} \leq 0.05)$ available in SPSS 16 statistical package. The values of the growth parameters of $C$. olitorius were presented in graphical forms to indicate the level of significance at $\mathrm{P} \leq 0.05$.

\section{Results \\ The pre-treatment analysis of the soil used for the experiment showed that the soil $\mathrm{pH}$ ranged between $6.20-6.70$ indicating a slightly acidic nature of the soil. The textural class of the soil was sandy loam. Table 1 shows the condition of the soil after incubation before planting, remarkable improvement was observed in the soil chemical properties when compared with control.}


Table 1 Incubation Effect of Agro-waste Amendments on Soil Chemical Properties before Planting of Corchorus olitorius

\begin{tabular}{|c|c|c|c|c|c|c|c|c|c|c|c|}
\hline \multirow[t]{2}{*}{ Treatments } & \multirow[t]{2}{*}{$\begin{array}{l}\text { Rates } \\
\text { (t/ha) }\end{array}$} & \multicolumn{2}{|c|}{$\mathrm{pH}$} & \multicolumn{2}{|c|}{$\mathrm{OC}$} & \multicolumn{2}{|c|}{$\mathrm{N}$} & \multicolumn{2}{|c|}{$\begin{array}{c}\mathrm{P} \\
\mathrm{mg} / \mathrm{kg} \quad \\
\end{array}$} & \multicolumn{2}{|c|}{$\begin{array}{c}\mathrm{CEC} \\
\mathrm{cmol} / \mathrm{kg} \\
\end{array}$} \\
\hline & & 6weeks & 12weeks & 6weeks & 12weeks & 6weeks & 12 weeks & 6weeks & 12 weeks & 6 weeks & 12weeks \\
\hline \multirow[t]{2}{*}{ CHA } & 5 & 6.30 & 6.35 & 13.28 & 14.59 & 0.83 & 0.76 & 1.92 & 1.84 & 4.12 & 3.69 \\
\hline & 10 & 6.50 & 6.40 & 14.33 & 15.73 & 0.73 & 0.79 & 1.72 & 1.61 & 4.66 & 4.36 \\
\hline \multirow[t]{2}{*}{$\mathrm{CHU}$} & 5 & 6.30 & 6.30 & 16.59 & 16.61 & 0.79 & 0.92 & 1.56 & 0.78 & 3.05 & 3.04 \\
\hline & 10 & 6.40 & 6.35 & 16.90 & 18.16 & 0.84 & 0.98 & 1.76 & 1.13 & 3.10 & 2.82 \\
\hline \multirow[t]{2}{*}{$\mathrm{CCA}$} & 5 & 6.35 & 6.35 & 15.11 & 13.94 & 0.75 & 0.76 & 1.63 & 1.25 & 3.04 & 3.07 \\
\hline & 10 & 6.45 & 6.40 & 15.27 & 15.59 & 0.76 & 0.78 & 1.94 & 1.35 & 2.92 & 3.03 \\
\hline \multirow[t]{2}{*}{$\mathrm{CCU}$} & 5 & 6.65 & 6.30 & 14.65 & 13.86 & 0.74 & 0.74 & 1.32 & 1.23 & 2.43 & 2.70 \\
\hline & 10 & 6.70 & 6.45 & 17.11 & 17.11 & 0.85 & 0.85 & 1.33 & 1.33 & 2.69 & 2.94 \\
\hline Control & 0 & 6.20 & 6.25 & 12.92 & 13.12 & 0.73 & 0.73 & 1.89 & 2.11 & 2.76 & 2.69 \\
\hline LSD & 0.05 & 0.002 & 0.002 & 0.001 & 0.003 & 0.227 & 0.072 & 0.144 & 0.000 & 0.201 & 0.071 \\
\hline
\end{tabular}

Legend: CHA - Coconut husk ash; CHU - Coconut husk unashed; CCA - Corn cob ash; CCU - Corn cob unashed 
Influence of Organic Wastes Amendment on Growth and Foliar Yield..................WWOTOYE et al.

The graphical format of growth parameters assessed are displayed in figures $1 \mathrm{a}$ and $\mathrm{b}$ through to figures $8 \mathrm{a}$ and $\mathrm{b}$.

\section{Plant Height}

Ashed corn cob and ashed coconut husk at 5 and $10 \mathrm{t} / \mathrm{ha}$ incubated soils for six weeks enhanced significantly the height of Corchorus olitorius compared with other treatments at 10 to 12 WAP. The shoot height of $C$. olitorius were significantly higher at $10-12$ WAP in soil pots amended for twelve weeks with $10 \mathrm{t} / \mathrm{ha}$ of ashed corn cob compared with pots amended with 10 t/ha of unashed corn cob.

\section{Total Leaf Count}

The total leaf count increased with the quantity of amendment used under six weeks incubated pots with ashed corn cob at 10 and 12 WAP. When compared with twelve weeks incubated pots especially at $10 \mathrm{t} / \mathrm{ha}$ there was observable reduction in leaf count of $C$. olitorius at 12 WAP.

\section{Stem Girth}

Stem girth of $C$. olitorius in $5 \mathrm{t} / \mathrm{ha}$ of ashed corn cob incubated pots was significantly higher than unashed corn cob incubated pots between 8 - 12 WAP, whereas in twelve weeks agro-wastes incubated pots, there were no significant difference in $C$. olitorius girth in pots with $5 \mathrm{t} / \mathrm{ha}$ ashed and unashed coconut husk. Though, both were significantly higher than pots with control.

\section{Leaf Area}

The leaf area of $C$. olitorius in pots amended with $5 \mathrm{t} / \mathrm{ha}$ ashed coconut husk for six weeks were significantly $(\mathrm{P}<0.05)$ higher compared with other agro-waste amended pots and the control between $6-8$ WAP. Pots amended with $5 \mathrm{t} / \mathrm{ha}$ of unashed coconut husk for twelve weeks increased leaf area of $C$. olitorius than pots amended with ashed coconut husk at 10-12 WAP. The reverse was the case with $5 \mathrm{t} / \mathrm{ha}$ ashed corn cob significantly increased the leaf area of $C$. olitorius compared with unashed corn cob between 8 - 12 WAP.

Generally, it was observed that at 12 WAP irrespective of application rate and incubation period of unashed corn cob in the soil, the plant height, leaf count, leaf area and stem girth of $C$. olitorius were reduced when compared with other amendments. Also $C$. olitorius grown in soils incubated for twelve weeks with various agrowaste at $10 \mathrm{t} / \mathrm{ha}$ showed drastic reduction in growth parameters and foliar yield when compared with $C$. olitorius grown in six weeks agrowaste amended soils

\section{Foliar Yield of C. olitorius}

The fresh weight of $C$. olitorius in six weeks amended soils with 5 and 10 t/ha CHA increased by 27 and $59 \%$, respectively, while values for dry weight increased by 90 and $200 \%$, respectively. The fresh weight of $C$. olitorius grown in soils amended with 5 and 10 t/ha CCA increased by 34 and $80 \%$, respectively, while the dry weight increased by 33 and $86 \%$, respectively.

The fresh weight of $C$. olitorius grown in twelve weeks amended soils with 5 and 10 t/ha CHA increased by 98 and $8 \%$, respectively, while the values for dry weight increased by 192 and $20 \%$ respectively. The fresh and dry weight of $C$. olitorius grown in soils amended with 5 t/ha CHU increased by $114 \%$ and $215 \%$, respectively. The fresh weight of $C$. olitorius grown in soils amended with 5 and 10 t/ha CCA increased by 60 and $16 \%$, respectively while the dry weight increased by 128 and $25 \%$, respectively as seen in Table 2 .

Table 2 Foliar Yield of Corchorus olitorius after Harvest

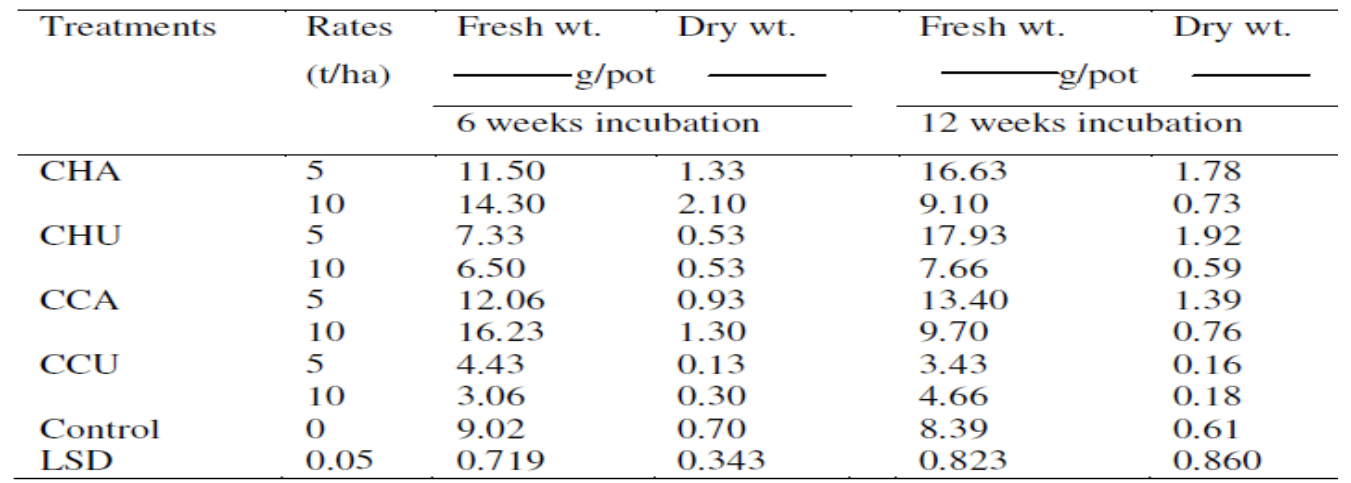

Legend: CHA - Coconut husk ash; CHU - Coconut husk unashed; CCA - Corn cob ash; CCU - Corn cob unashed 

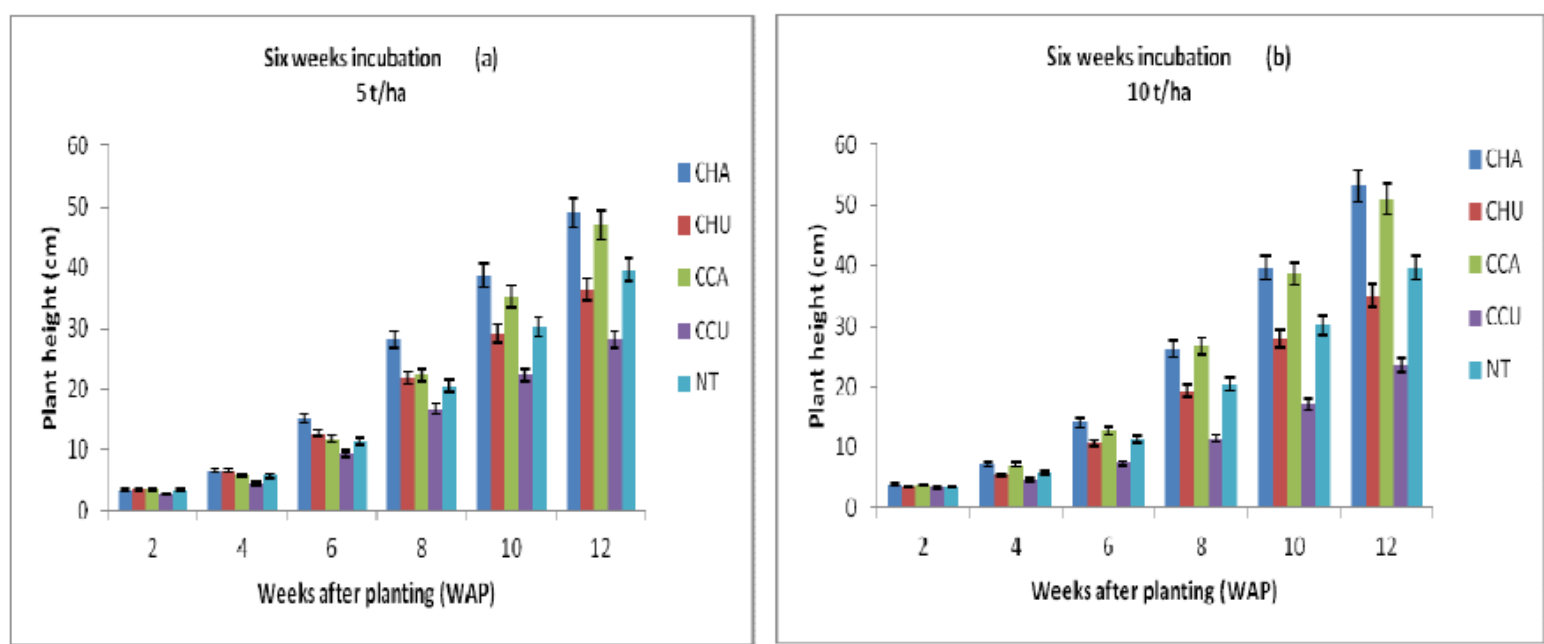

Figures $1 \mathrm{a}$ and b: Effect of 6-weeks soil incubated agro-wastes on the plant height $(\mathrm{cm})$ of $C$. olitorius.

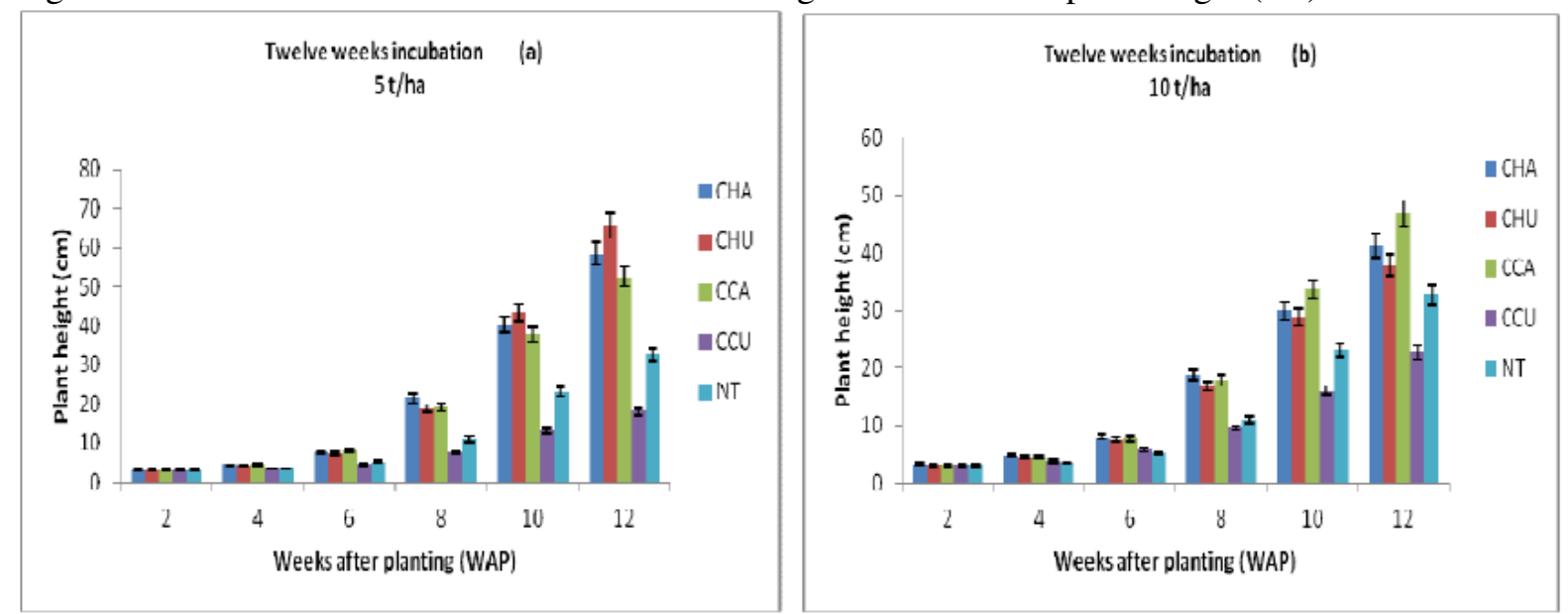

Figures 2 a and b: Effect of 12-weeks soil incubated agro-wastes on the plant height $(\mathrm{cm})$ of $C$. olitorius.
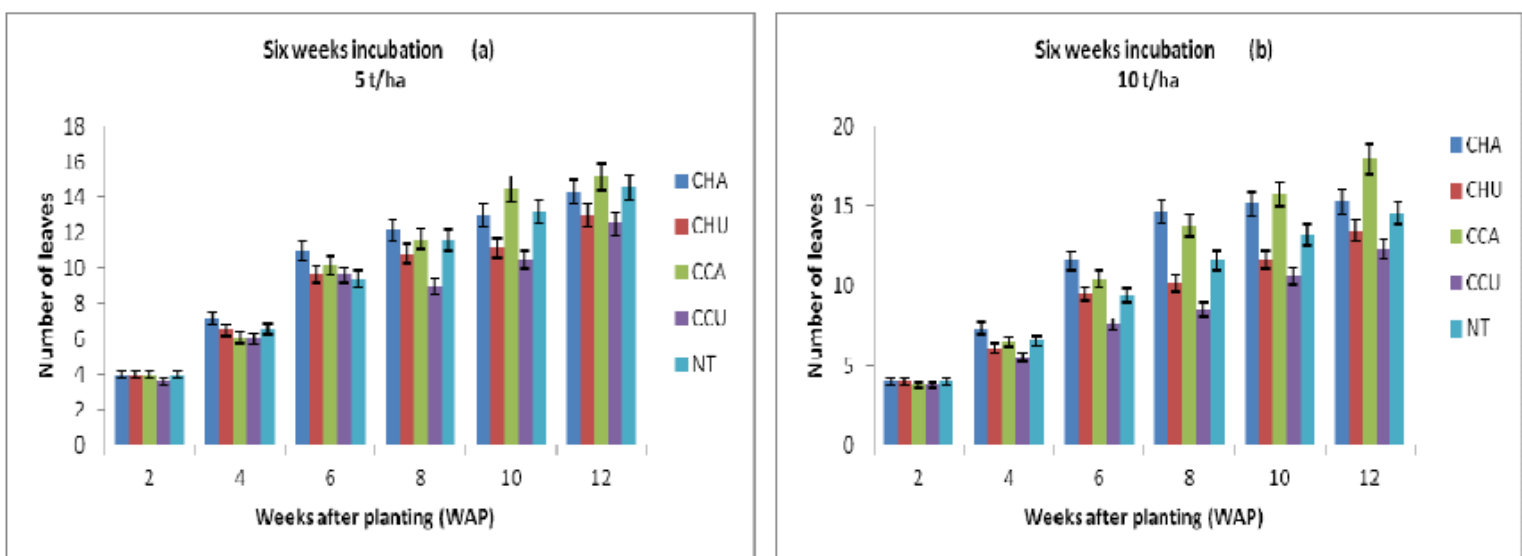

Figures 3 a and b: Effect of 6-weeks soil incubated agro-wastes on the total leaf count of $C$. olitorius. Vertical error bars at $5 \%$ value Legend: CHA - Coconut husk ash; 

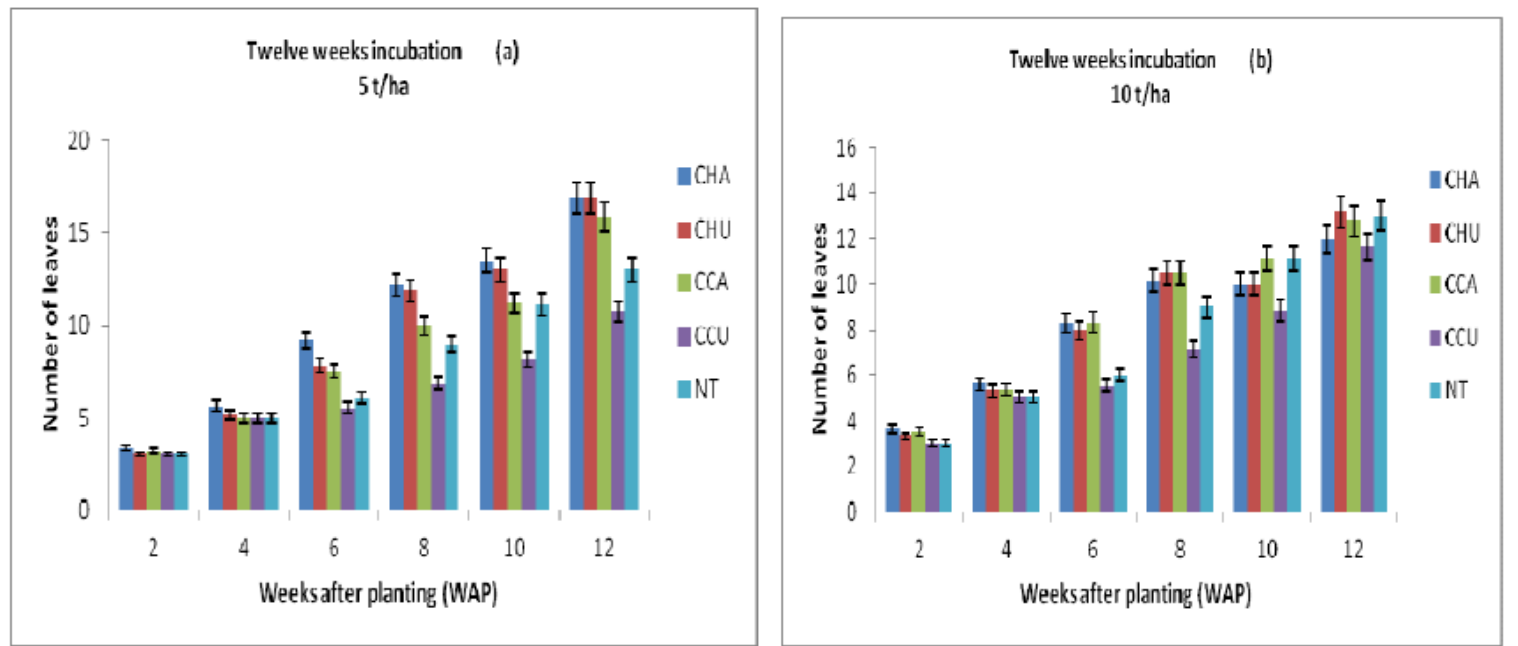

Figures $4 \mathrm{a}$ and b: Effect of 12-weeks soil incubated agro-wastes on the total leaf count of C. olitorius.
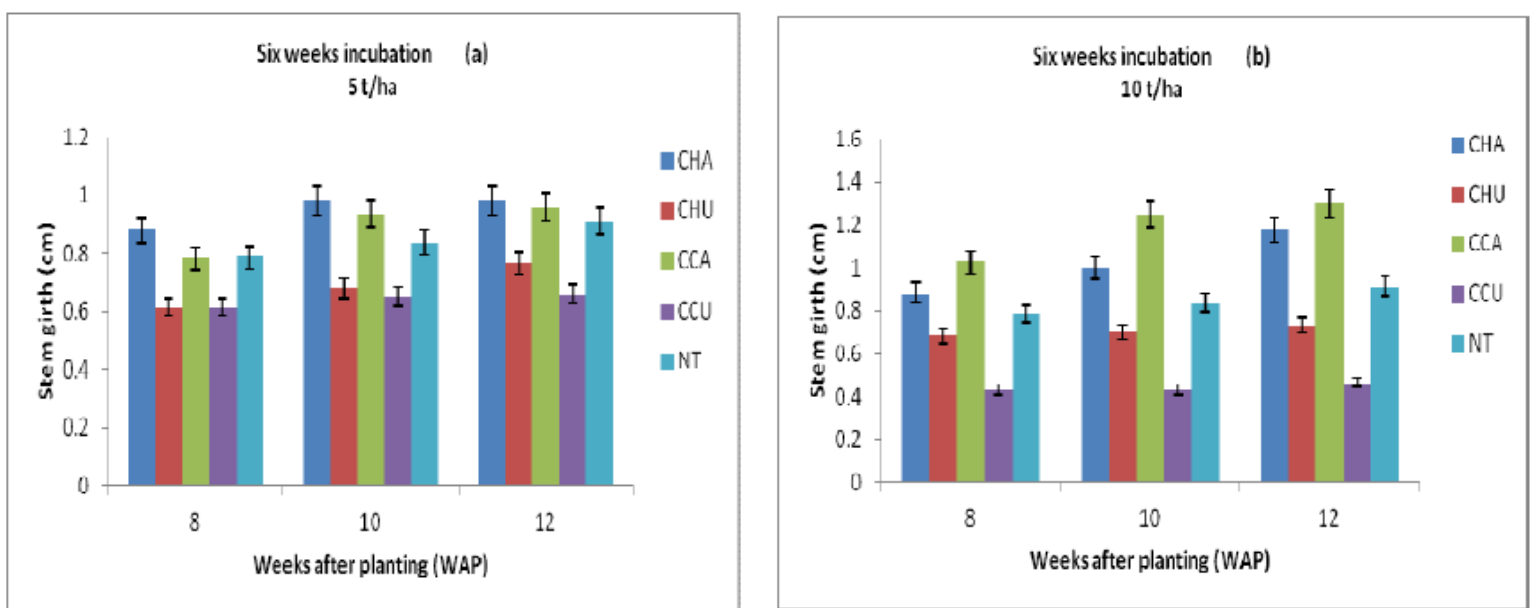

Figures $5 \mathrm{a}$ and b: Effect of 6-weeks soil incubated agro-wastes on the stem girth (cm) of C. olitorius.

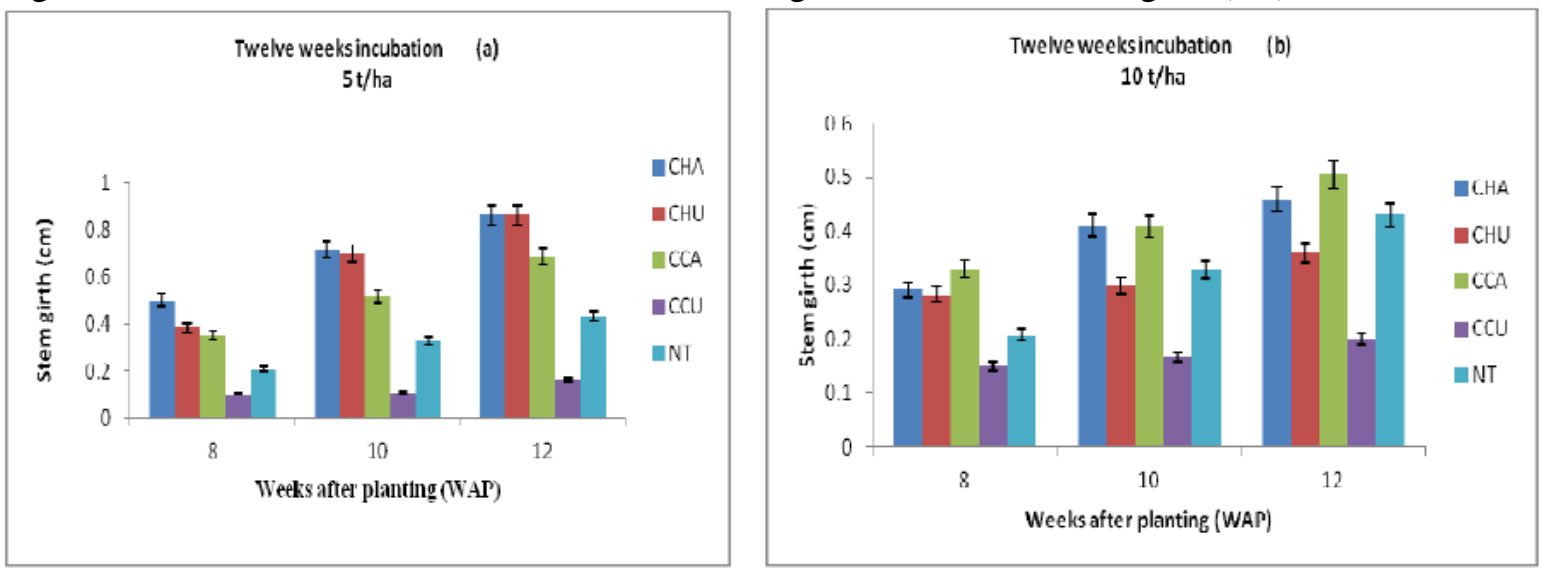

Figures $6 \mathrm{a}$ and b: Effect of 12-weeks soil incubated agro-wastes on the stem girth $(\mathrm{cm})$ of $C$. olitorius.

Vertical error bars at $5 \%$ value

Legend: CHA - Coconut husk ashed; CHU - Coconut husk unashed; CCA - Corn cob ashed; CCU - Corn cob unashed NT - No amendment 

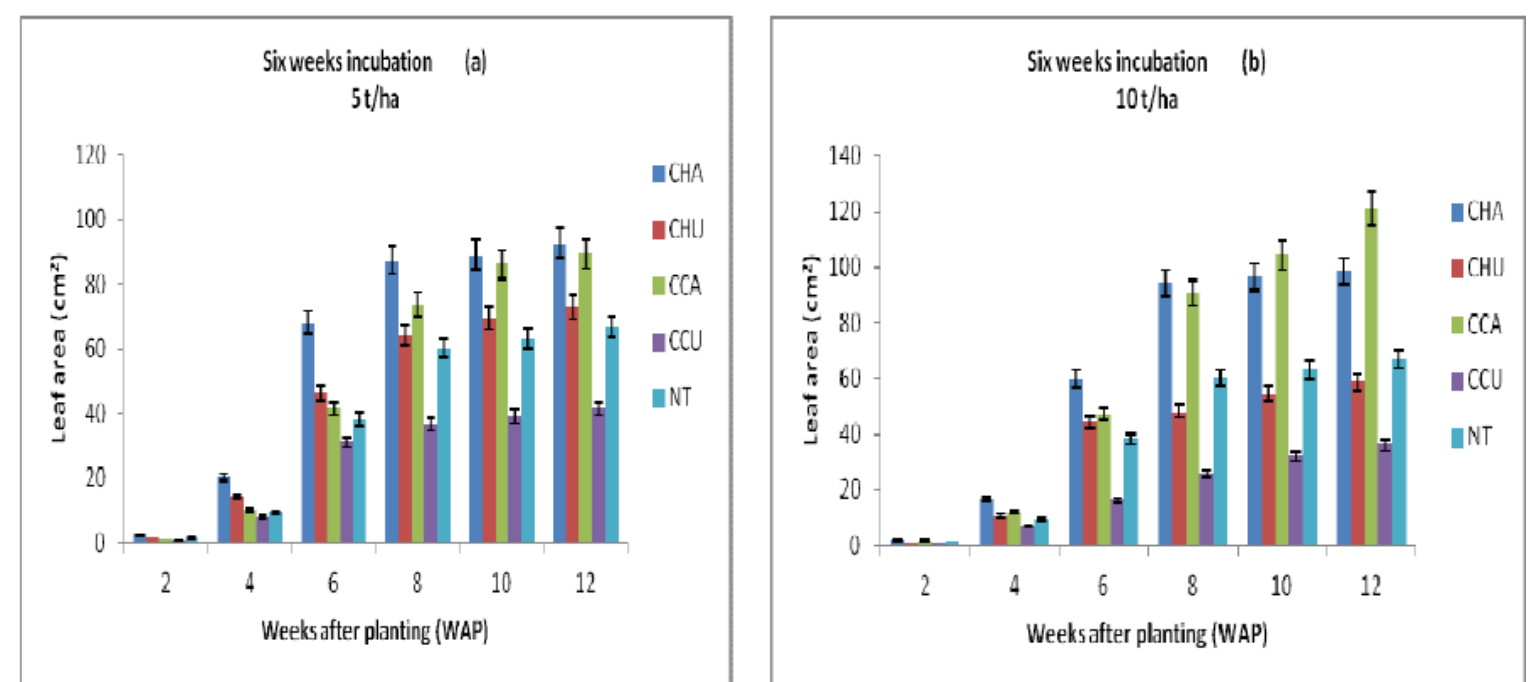

Figures 7 a and b: Effect of 6-weeks soil incubated agro-wastes on the leaf area $\left(\mathrm{cm}^{2}\right)$ of C. olitorius.
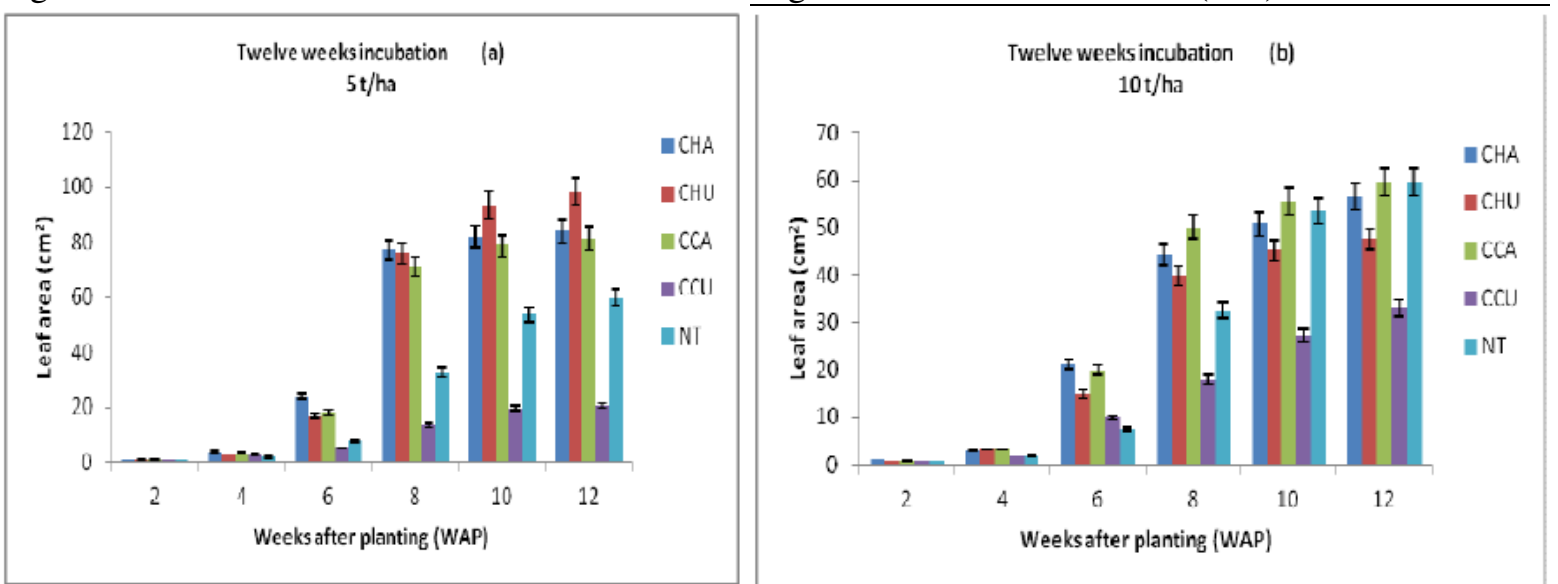

Figures $8 \mathrm{a}$ and b: Effect of 12-weeks soil incubated agro-wastes on the leaf area $\left(\mathrm{cm}^{2}\right)$ of $C$. olitorius.

Error bars at $5 \%$ value

Legend: CHA - Coconut husk ashed; CHU - Coconut husk unashed; CCA - Corn cob ashed; CCU - Corn cob unashed NT - No amendment

\section{Discussion}

\section{Influence of Incubated Soil Amendments on Growth and Biomass Yield of C. olitorius}

Soil amendments most frequently are used to provide essential nutrients (such as $\mathrm{N}$ and $\mathrm{P}$ and $\mathrm{K}$ ), thereby improving the physico-chemical properties of such soils. Soils amended at 5 and 10 t/ha with ashed corn cob and ashed coconut husk for six weeks improved the plant height of C. olitorius consecutively relative to pots with unashed corn cob and coconut husk. This could have been as a result of quick mineralization due to ashing. Soils amended at $5 \mathrm{t} / \mathrm{ha}$ of unashed coconut husk in twelve weeks incubated pots recorded the highest plant height relative to pots incubated at six weeks with agro-wastes amendments at 12 WAP. Subsequently, there was a reduction in plant height at $10 \mathrm{t} / \mathrm{ha}$ in twelve weeks amended pots. Soils amended with unashed corn cob at 5 and $10 \mathrm{t} / \mathrm{ha}$ significantly (p $<0.05$ ) reduced plant height of $C$. olitorius in both incubation periods (six and twelve weeks) over other amendments at 12 WAP. Oladipo et al. (2010) also observed that sawdust application and PM + SD (1:1) significantly reduced the plant height of maize over other treatments. Findings of Moyin-Jesu (2008), Olayinka (1990, 1996) also observed reduction in plant growth in sawn-dust amended soils and attributed it to 
Influence of Organic Wastes Amendment on Growth and Foliar Yield..................WWOTOYE et al.

immobilization of nutrients due to its carbonaceous nature.

Ashed corn cob at $10 \mathrm{t} / \mathrm{ha}$ in six weeks incubated soil improved the total leaf count, stem girth and leaf area of $C$. olitorius relative to those amended for twelve weeks. Odedina et al. (2003) observed that the good performance of plant parameters measured could be attributed to an improvement in soil $\mathrm{pH}$ and general fertility of soil which resulted from the application of the ash.

Twelve weeks soil incubated unashed coconut husk at 5 t/ha gave the highest fresh weight and dry weight for $C$. olitorius. This could mean that twelve weeks for incubation of unashed coconut husk was sufficient for its mineralization. The least fresh and dry weight of C. olitorius was observed in pots amended with six and twelve weeks incubated unashed corn cob. This trend appears to confirm the immobilizing potential of unashed corn cob. Oladipo et al. (2010) observed that at the end of both plantings of maize, the dry matter yields decreased as the ratio of sawn dust in the poultry manure-sawn dust mixture increased.

\section{Conclusion}

Considering the high cost, scarcity, and environmental problems associated with the use of mineral fertilizer in Nigeria, as well as the menace indiscriminate waste disposal poses to our immediate environment and based on the increased foliage yield obtained in this study. It was obvious that the agrowastes excluding unashed corn cob, would be a rewarding venture if adopted for $C$. olitorius production in problem soils of South-West Nigeria. Appropriate timing and application rate is also essential as $C$. olitorius grown in pots incubated at six weeks did better in almost all the growth parameters assessed than $C$. olitorius grown in twelve weeks agrowastes incubated pots at both applications rate.

\section{References}

Adeleye, E. O, Ayeni, L. S. and Ojeniyi, S. O. (2010). Effect of poultry manure on soil physico-chemical properties, leaf nutrient contents and yield of yam (Dioscorea rotundata) on alfisol in southwestern Nigeria. J. Am. Sci. 6(10): 956-959
Adeniyan, O. N. and Ojeniyi, S. O. (2003). Comparative effectiveness of different levels of poultry manure with NPK fertilizer on residual soil fertility, nutrient uptake and yield of maize. J. Agric. Res. 2: 191-197

Agboola, A. A. and Unamma, R. P. A. (1991) Maintenance of soil fertility under traditional farming systems. In: Proceedings of National Organic Fertilizer Seminar held at Durbar Hotel, Kaduna, Nigeria, March 26-27, pp 7-20

Alabadan, B. A., Adeoye, P. A., and Folorunso, E. A. (2009). Effect of different poultry wastes on physical, chemical and biological properties of soil. Caspian $J$. Environ. Sci. 7(1): $\quad 31-35$

Ayeni, L. S. (2009). Comparative nutrient release from combined cocoa pod ash, poultry manure and NPK 20:10:10 fertilizer on major soil nutrients in southwest Nigeria incubation study International Journal of Soil Science 1(1): 42-46

Ayeni, L. S. (2010). Effect of cocoa pod ash, NPK fertilizer and their combinations on soil chemical properties and yield of tomato (Lycopersicon lycopersicum) on two soil types. New York Journal 3(4): $1-11$

Ayeni, L. S., Adetunji, M. T., and Ojeniyi, S. O. (2008). Comparative nutrient release from cocoa pod ash, poultry manure and NPK 20:10:10 fertilizer and their combinations - incubation study.

Nigerian Journal of Soil Science 18: 23-26

FMAWR (1988). Agricultural policy for Nigeria: strategies for implementation. Lagos, Federal Ministry of Agriculture, Water Resources and Rural Development.

Husselman, M. and Sizane, N. (2006). Imifino, A Guide to the use of Wild Leafy Vegetables in the Eastern Cape. ISER Monograph Two. Institute for Social and Economic Research, Rhodes University, Grahamstown, South Africa

Jamil, M., Qasim, M., Umar, M. and Subhan, A. (2004). Impact of organic wastes (bagasse ash) on the yield of wheat (Triticum aestivum L.) in a calcareous soil. International Journal of Agriculture and Biology 6(3): 468-470 
Kra, E. and Bani, R.J. (1988). Handling and transportation of vegetables in Ghana. Agricultural mechanization in Asia, Africa and Latin America. AMA 19(2): 52-54.

Mbah, C. N. (2006). Influence of organic wastes on plant growth parameters and nutrient uptake by maize (Zea mays L.). Nigeria J. Soil Sci. 16: 104-108

Mofeke, A.L.E., Ahmada, A. and Mudiane, O.J. (2003). Relationship between yield and seasonal water use for tomatoes, onions and potatoes grown under fadama irrigation Asset Series A. 3: 35-46

Moyin-Jesu, E.I. (2008). Evaluation of different organic fertilizers on the soil, leaf chemical composition and growth performance of coffee seedlings (Coffee Arabica L.) African Journal of Science and Technology (AJST) Science and Engineering 9(2): 105-112

Musa, A., Ezenwa, M.I.S., Oladiran, J.A., Akanya, A.O. and Ogbadoyi, E.O. (2010). Effect of soil nitrogen levels on some micronutrients, anti-nutrients and toxic substances in Corchorus olitorius grown in Minna, Nigeria. African Journal of Agricultural Research 5(22): 3075-3081

Njoku, C. and Mbah, C.N. (2012). Effect of burnt and unburnt rice husk dust on maize yield and soil physico-chemical properties of an ultisol in Nigeria. International Journal for Sustainable Production Systems 28(1): 49-60

Odedina, S.A., Odedina, J.N., Ayeni, S.O., Arowojolu S.A., Adeyeye, S.D. and Ojeniyi, S.O. (2003). Effect of types of ash on soil fertility, nutrient availability and yield of tomato and pepper. Nigerian Journal of Soil Science 13: 61-67

Oladipo, O.G., Olayinka, A. and Aduayi, E.A. (2010). Organic amendments and their effects on some soil chemical properties and maize (Zea mays L.) performance. African Journal of Science and Technology 11(1): 61-67

Oladiran, J.A. (1986). Effect of stage of harvesting and seed treatment on germination, seedling emergence and growth in Corchorus olitorius 'Oniyaya'. Sci. Hortic. 28: 227-233

Oladoja, M.A., Adisa, B.O. and Ahmed-Akinola, A.A. (2006). Effectiveness of communication method used in information delivery to cocoa farmers in Oluyole Local Government Area, Oyo State, Nigeria. The Ogun Journal of Agric. Sci. 4: 78-88

Olayinka, A. (1996). Carbon mineralization from poultry-manure straw sawdust amended alfisol. Ife Journal of Agriculture 1\&2 (18): 26-36

Olayinka, A. (1990). Effects of poultry manure, corn straw and sawdust on plant growth and soil chemical properties. Ife Journal of Agriculture 7(1\&2): 1-5

Olorunnisola, A.O. (2009). Effects of husk particle size and calcium chloride on strength and sorption properties of coconut husk-cement composites. Industrial Crops and Products 29(2-3): 495-501. 